\title{
A fruit quality gene map of Prunus
}

\section{Ebenezer A Ogundiwin*1, Cameron P Peace ${ }^{2}$, Thomas M Gradziel1, Dan E Parfitt ${ }^{1}$, Fredrick A Bliss ${ }^{1}$ and Carlos H Crisosto ${ }^{1}$}

\author{
Address: ${ }^{1}$ Plant Sciences Department, University of California Davis, 1 Shields Ave., Davis CA 95616, USA and ${ }^{2}$ Department of Horticulture and \\ Landscape Architecture, Washington State University, Pullman, WA 99164 USA \\ Email: Ebenezer A Ogundiwin* - ogundiwin@gmail.com ; Cameron P Peace - cpeace@wsu.edu; Thomas M Gradziel - tmgradziel@ucdavis.edu; \\ Dan E Parfitt - deparfitt@ucdavis.edu; Fredrick A Bliss - fbliss@dcn.org; Carlos H Crisosto - carlos@uckac.edu \\ * Corresponding author
}

Published: 8 December 2009

BMC Genomics 2009, 10:587 doi:10.1/86/147|-2164-10-587
Received: 16 March 2009

Accepted: 8 December 2009

This article is available from: http://www.biomedcentral.com//47/-2/64/10/587

(C) 2009 Ogundiwin et al; licensee BioMed Central Ltd.

This is an Open Access article distributed under the terms of the Creative Commons Attribution License (http://creativecommons.org/licenses/by/2.0), which permits unrestricted use, distribution, and reproduction in any medium, provided the original work is properly cited.

\begin{abstract}
Background: Prunus fruit development, growth, ripening, and senescence includes major biochemical and sensory changes in texture, color, and flavor. The genetic dissection of these complex processes has important applications in crop improvement, to facilitate maximizing and maintaining stone fruit quality from production and processing through to marketing and consumption. Here we present an integrated fruit quality gene map of Prunus containing I 33 genes putatively involved in the determination of fruit texture, pigmentation, flavor, and chilling injury resistance.
\end{abstract}

Results: A genetic linkage map of 211 markers was constructed for an intraspecific peach (Prunus persica) progeny population, Pop-DG, derived from a canning peach cultivar 'Dr. Davis' and a fresh market cultivar 'Georgia Belle'. The Pop-DG map covered 818 cM of the peach genome and included three morphological markers, II ripening candidate genes, I3 cold-responsive genes, 2 I novel EST-SSRs from the ChillPeach database, 58 previously reported SSRs, 40 RAFs, 23 SRAPs, 14 IMAs, and 28 accessory markers from candidate gene amplification. The Pop-DG map was co-linear with the Prunus reference T $\times$ E map, with 39 SSR markers in common to align the maps. A further 158 markers were bin-mapped to the reference map: 59 ripening candidate genes, 50 coldresponsive genes, and 50 novel EST-SSRs from ChillPeach, with deduced locations in Pop-DG via comparative mapping. Several candidate genes and EST-SSRs co-located with previously reported major trait loci and quantitative trait loci for chilling injury symptoms in Pop-DG.

Conclusion: The candidate gene approach combined with bin-mapping and availability of a community-recognized reference genetic map provides an efficient means of locating genes of interest in a target genome. We highlight the co-localization of fruit quality candidate genes with previously reported fruit quality QTLs. The fruit quality gene map developed here is a valuable tool for dissecting the genetic architecture of fruit quality traits in Prunus crops.

\section{Background}

Molecular genetic linkage maps have become a major tool in genetics, genomics and breeding of plant and animal species. Linkage maps provide opportunities for unlocking the complex genetics of quantitatively inherited traits through the localization of quantitative trait loci (QTL), 
identification and positional cloning of individual genes, development of genome-wide physical maps, assembly and annotation of whole genome sequence, and serve as a repository of markers useful in marker-assisted breeding $(\mathrm{MAB})$ of crop and animal species. Among the most informative maps for $\mathrm{MAB}$ are those constructed using parent genotypes directly involved in breeding programs.

Peach is one of the best genetically characterized species in the Rosaceae family $[1,2]$, and the most economically important crop in Prunus [1], a genus that also includes nectarine, plum, apricot, cherry, and almond. The small genome size and expanding genomic resources of peach highlight peach as a model species for genomics studies of tree fruits [1-4]. Details of these genetic and genomic resources are updated and described on the Genomic Database for Rosaceae (GDR) [5].

While numerous Prunus species linkage maps have been published, the interspecific linkage map $(\mathrm{T} \times \mathrm{E})$ developed from an interspecific cross of almond ("Texas") with peach ("Earlygold") is the most saturated of all these linkage maps [6-8]. Due to this saturation, a high degree of polymorphism, and extensive co-linearity and synteny among Prunus genomes $[9,10]$, research community consensus has established the $\mathrm{T} \times \mathrm{E}$ map as the reference map for all Prunus species. The most recent published version of the $\mathrm{T} \times \mathrm{E}$ map contains 562 markers spanning $519 \mathrm{cM}$ with an average density of $0.9 \mathrm{cM}$ per marker [8]. Building on the reference status of $\mathrm{T} \times \mathrm{E}$, a bin-mapping strategy was developed [11]. In this technique, recombination patterns in six progeny of the $\mathrm{T} \times \mathrm{E}$ mapping population were used to reduce the Prunus genome to 67 "bins" of $7.8 \mathrm{cM}$ average length and to further populate the reference map with an additional 264 microsatellite-derived markers [11]. Other interspecific Prunus linkage maps were derived from almond 'Padre' $\times$ peach selection 54P545 [12,13], and myrobalan plum clone P.2175 $\times$ almond-peach hybrid clone GN22 [14]. Interspecific maps are easily saturated with markers due to the high level of polymorphism between parent genotypes. However, they are limited in their immediate applicability to cultivar improvement via MAS when compared to intraspecific maps because markers that are polymorphic between species are often not polymorphic within species. This is especially true for peach which has a narrow genetic base [15]. Reported intraspecific Prunus linkage maps include those of almond [16-18], apricot [19-22], sweet cherry [23], and peach [15,24-29]. The ultimate stated goal of most linkage map construction efforts for Prunus crop species is the development of breeder-friendly MAB tools. Potential benefits of $M A B$ are particularly great for these crop species because of their long juvenility and requirements for large field planting spaces.
The concept of fruit quality of Prunus fruit crops includes both its attainment, such changes in color, flavor, and texture as fruit develop, grow, and ripen, and its maintenance following harvest from the tree as the perishable tissues senesce. Prunus fruit development, growth, ripening, and senescence includes major biochemical and sensory changes in texture, color, and flavor. The genetic dissection of these complex processes has important applications in crop improvement, to facilitate maximizing and maintaining stone fruit quality from production and processing through to marketing and consumption.

The goal of the present study was to develop a genomic resource to facilitate the genetic dissection of Prunus fruit quality traits. This paper reports the genetic mapping in the Prunus genome of candidate genes for fruit texture, pigmentation, flavor, and cold-responsiveness of peach, using both an intraspecific peach population to create a linkage map for genetic analyses of fruit quality and chilling injury (CI), and the interspecific Prunus reference map. The utility of the "fruit quality gene map" developed here for Prunus is demonstrated by highlighting co-localization of fruit quality QTLs with mapped fruit quality candidate genes.

\section{Results \\ Morphological markers}

Peach blossom petals can be large and showy or small and curved on margins (non-showy). Non-showy is dominant to showy [30]. 'Dr. Davis' and 'Georgia Belle' are both heterozygous and therefore non-showy for this locus. PopDG progeny segregated as 115 non-showy: 37 showy, fitting the expected Mendelian ratio of $3: 1\left({ }^{2}=0.04 ; P=\right.$ 0.98 ). This trait was designated $S h$ and mapped to the middle of linkage group G8 of Pop-DG and flanked by SSR marker CPPCT006 at $5 \mathrm{cM}$ above and CI resistance CG marker Unk5 at $11.2 \mathrm{cM}$ below. Segregation and mapping of the peach mesocarp color $(Y)$ and the freestone melting flesh (F-M) loci have been reported previously for Pop-DG $[31,32]$.

\section{Molecular marker polymorphism in Pop-DG}

Three types of reproducible marker polymorphism were observed on the PAGE profiles of the CG PCR products: fragment size polymorphism of the targeted gene fragments, additional markers that were designated as "CG accessory markers" generated elsewhere in the profile than the main CG fragments, and single strand conformation polymorphism (SSCP). Under the conditions used for PAGE, some reproducible sharp or shadowy banding patterns were observed in association with the target PCR product. We have proved this to be mobility shifts characteristic of SSCP resulting from SNPs within the amplicons [33]. The SSCP phenomenon also occurred for many SSRs (Figure 1). 


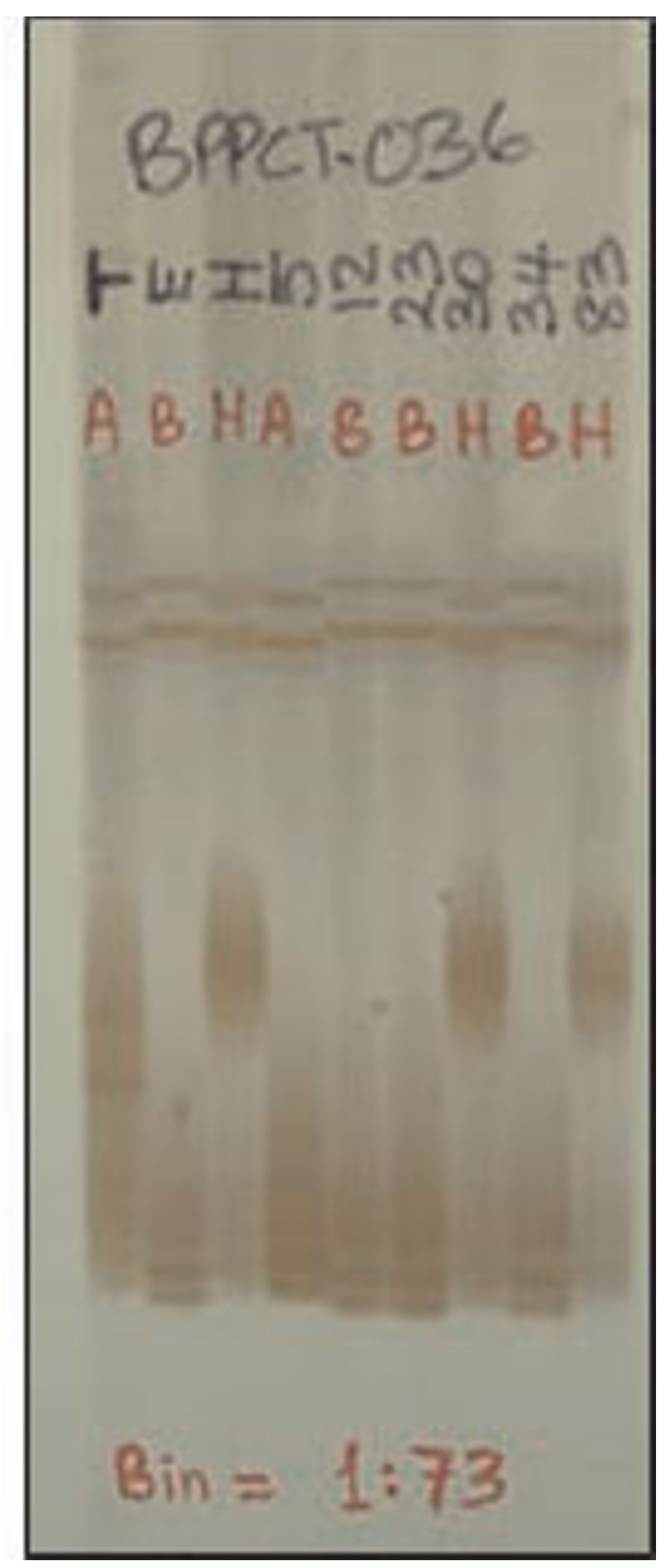

Figure I

Polyacrylamide gel profile of SSR marker BPPCT036. The gel profile shows the re-assignment of BPPCT036 from linkage group G4 (bin 4:63) to bin I:73 on the Prunus T $\times$ E reference map.
Of all 229 SSR primer pairs screened for polymorphism in Pop-DG, 68 ( $30 \%)$ were polymorphic and produced 79 SSR markers (Figure 2). Polymorphism was higher in the 133 genomic SSRs (37\%) than in the 96 EST-SSRs (23\%). Of the 76 novel ChillPeach EST-SSRs tested in Pop-DG, 17 $(22 \%)$ were polymorphic, on par with the public EST-SSR polymorphism. The remaining 59 ChillPeach EST-SSRs were screened on the $\mathrm{T} \times \mathrm{E}$ bin set, out of which 51 (86\%) were polymorphic. Approximately $13 \%$ and $18 \%$ polymorphism was obtained for CI resistance CGs and other CGs in Pop-DG, respectively, while $71 \%$ and $86 \%$ polymorphism was obtained in $\mathrm{T} \times \mathrm{E}$, respectively (Figure 2 ). Marker polymorphism in Pop-DG was therefore at least four to five times less than in $\mathrm{T} \times \mathrm{E}$ for all classes of marker tested.

\section{Pop-DG linkage map}

The Pop-DG intraspecific peach linkage map contained a total of 211 markers (208 molecular and three morphological) distributed over eight linkage groups corresponding to the haploid chromosome number of peach (Figure $3)$. The map covered $818.2 \mathrm{cM}$ of the peach genome with an average of $4.0 \mathrm{cM}$ interval between markers. The markers on Pop-DG map consisted of three Mendelian trait loci, 24 CGs, 79 SSRs, 40 RAFs, 23 SRAPs, 14 IMAs, and 28 CG accessory markers associated with CGs. Of the 79 SSR markers on Pop-DG, 39 were shared with the published Prunus $\mathrm{T} \times \mathrm{E}$ reference map (Figure 3 ). These common markers enabled the determination of linkage group orientation and assignment of linkage group numbers for the Pop-DG map. Shared markers were co-linear between Pop-DG and $\mathrm{T} \times \mathrm{E}$ except in three cases. Marker positions for BPPCT024, ВРPCT030, and pchgms1 were inverted at the lower end of linkage group G2 of Pop-DG compared to G2 of T $\times$ E, positions of BPPCT021 and UDP96-008 were inverted in the middle of G3 of Pop-DG compared to $\mathrm{G} 3$ of $\mathrm{T} \times \mathrm{E}$, and positions of ВРРСТ026 and СРРСТ004 were inverted towards the upper end of G5 of Pop-DG compared to G5 of T $\times$ E. One SSR marker (BPPCT036) that was originally placed on linkage group G4 of T $\times$ E [7] mapped to the distal end of G1 in Pop-DG. To resolve this discrepancy, BPPCT036 was tested on the $\mathrm{T} \times \mathrm{E}$ bin set which confirmed its true location in bin 1:73 (Figure 1), corresponding to its position on the Pop-DG linkage map.

The features of CGs mapped to Pop-DG are presented in Table 1. Eleven markers were derived from fruit qualityrelated CGs (Table 1), seven of which were texture CGs. One of these texture CGs, endoPG (endopolygalacturonase), mapped to linkage group G4 as previously reported (Peace et al. 2005a). The others were two pectin methylesterases (PME1 \&PME5) on G1 and G7, another polygalacturonase (PG4) on G8, pectate lyase (PL2) on G1, alpha-L-arabinofuranosidase (Ara) on G5, and a MADS 


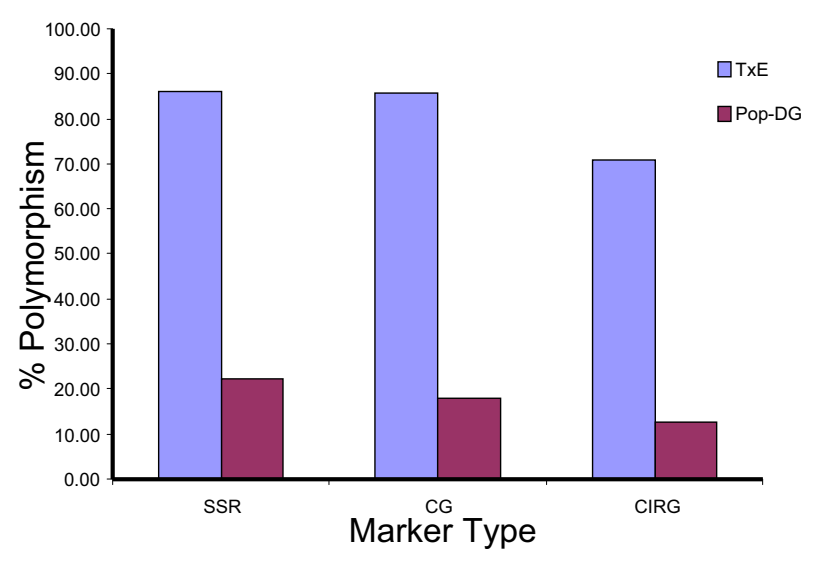

Figure 2

Level of polymorphism of three molecular marker types in Pop-DG and T $\times$ E. The intraspecific peach population (Pop-DG) compared with the interspecific Prunus population $(T \times E) ; S S R=$ simple sequence repeat, $C G=$ fruit ripening candidate genes, $\mathrm{CIRG}=\mathrm{Cl}$ resistance genes.

box transcription factor similar to tomato ripening inhibitor (RIN) on G4. Three pigmentation CGs mapped to Pop-DG. These were beta-carotene hydroxylase $(\mathrm{BCH})$ on G2, leucoanthocyanidin dioxygenase (PpLDOX) on G5 as previously reported by Ogundiwin et al. (2008), and zeaxanthin epoxidase (ZXE2) on G7. A flavor CG for sucrose phosphate synthase (SPS) mapped to G1. Thirteen mapped Pop-DG gene markers were obtained from CI resistance CGs. Seven of these have functional annotation: Aux/IAA protein $(A u x-I A A)$ on G1, chloroplast nucleoid DNA binding (CND) on G1, thaumatin-like protein 1 precursor (TP1) on G3, serine protease-like protein (SPP) on G7, tonoplast intrinsic protein (TIP) on G7, indole-3-acetic acid-induced protein ARG2 (Arg2) on G8, and sulfate transporter (ST) on G8. The other six had no functional annotation (labeled with the prefix "Unk" for "unknown") on G1, G2, G3, G8, and two on G6. Some dominant markers were generated from accessory fragments amplified alongside major amplicons of a few candidate genes (See Additional file 1 - Table S1). Seventeen of such markers were mapped to Pop-DG.

Features of the 18 ChillPeach ESTs that produced 21 ESTSSRs mapped to Pop-DG are provided (See Additional file 2 - Table S2). Eight of these have annotated functions: two zinc finger-RING type, thioredoxin domain 2, POZ/BTB containing protein, biotin synthase, lysine ketoglutarate reductase, transfactor-like protein, TRNA intron endonuclease, and farnesyltransferase beta subunit. Other ChillPeach EST-SSRs on Pop-DG have no known functional annotation.

\section{Bin-mapping CGs and ChillPeach EST-SSRs to the Prunus reference $T \times E$ map}

The bin-mapping technique developed for the Prunus $\mathrm{T} \times$ E reference map enabled the mapping of 158 markers that were monomorphic in Pop-DG (Figure 4; See Additional file 3 - Table S3). These included 109 CGs and 49 novel ChillPeach EST-SSRs. The bin-mapped CGs included 35 texture and nine pigmentation CGs. All markers mapped to 53 of the $67 \mathrm{~T} \times \mathrm{E}$ bins. Approximately 30 of the 50 binmapped ChillPeach EST-SSR markers (60\%) were derived from ESTs with known GO annotations (See Additional file 2 - Table S2). Others were unknown.

\section{Discussion}

We have developed a detailed fruit quality and ripening gene map for Prunus. The fruit quality gene map contains 133 candidate genes (CGs) implicated in fruit ripening, softening, flavor, and pigmentation, and chilling injury resistance. The Pop-DG peach map is almost entirely colinear with the Prunus reference $\mathrm{T} \times \mathrm{E}$ map such that locations of markers and quantitative trait loci (QTLs) located on Pop-DG can be readily cross-referenced to $\mathrm{T} \times \mathrm{E}$ and other Prunus maps aligned to T $\times$ E. Similarly, markers and QTLs in other Prunus maps (and other Rosaceae crop maps as comparative genomics advances in this family) can be compared to the Prunus fruit quality gene map to identify genes controlling fruit ripening and sensory quality.

\section{Co-linearity between Pop-DG and $T \times E$ maps}

Using a reference genetic map with available bin-mapping resources to map genes and other DNA sequences not polymorphic within crop-specific maps is a powerful means of identifying marker-trait associations. The degree of resolution offered by bin-mapping in $\mathrm{T} \times \mathrm{E}$ ( 1 to $30 \mathrm{cM}$ bins) is at the same scale as typical QTL mapping, such that detection of co-location (and equally useful, lack of colocation) of candidate genes with previously mapped QTLs is readily achievable. The remarkable conservation of co-linearity among the genomes of Prunus species [8] was exploited by bin-mapping to the $\mathrm{T} \times \mathrm{E}$ reference map many CGs that were monomorphic in Pop-DG. The higher rate of polymorphism observed in $\mathrm{T} \times \mathrm{E}$ compared to Pop-DG is not surprising because $\mathrm{T} \times \mathrm{E}$ is an $\mathrm{F}_{2}$ population from an interspecific cross. Pop-DG's polymorphism results from a relatively high heterozygosity in 'Georgia Belle' compared to modern cultivars, low heterozygosity in 'Dr. Davis' arising from a pedigree of closely related yellow non-melting canning peaches, and divergent breeding histories of these two parent cultivars. We expect that intraspecific peach populations derived from modern cultivars within the same market type (fresh or canning) will display even less polymorphism than Pop-DG. Inversion of marker positions observed between Pop-DG and $\mathrm{T} \times \mathrm{E}$ 

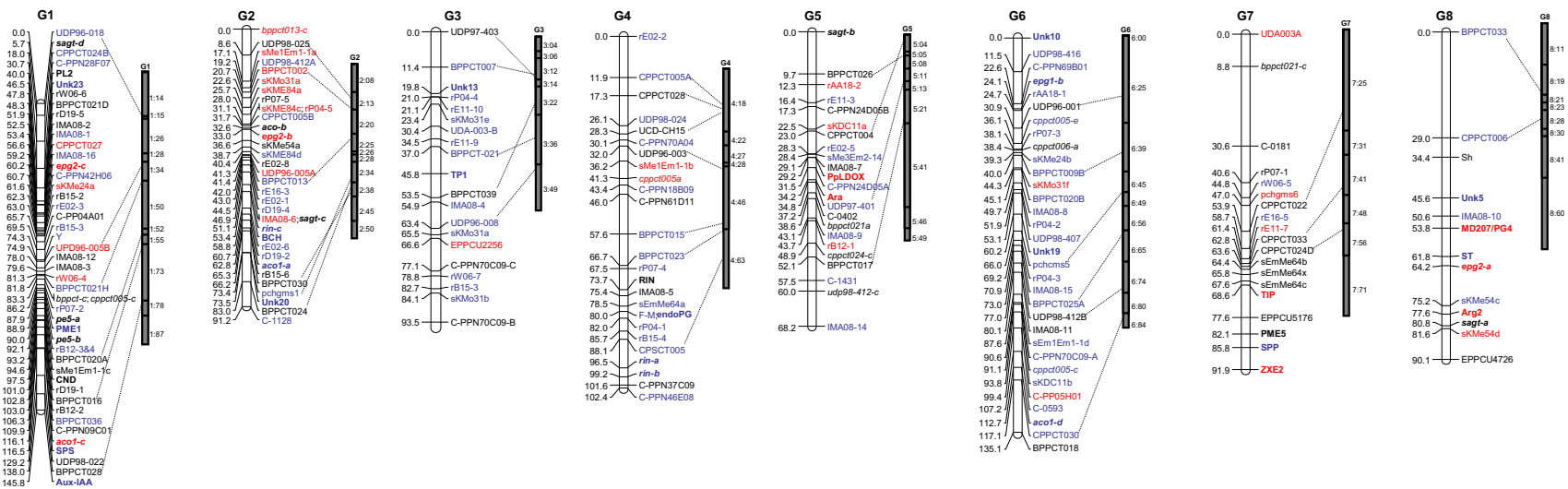

\section{Figure 3}

Genetic linkage map of Pop-DG with fruit texture, flavor, pigment, and CI resistance genes. Pop-DG = 'Dr. Davis $\times$ 'Georgia Belle'. Open vertical bars represent linkage groups. Vertical solid bars represent linkage groups of the $T$ × E Prunus reference map (Dirlewanger et al. 2004; Howard et al. 2005) showing the bins and anchored with linkage groups of Pop-DG. Positions of SSR markers on the T $\times$ E map corresponding to the Pop-DG map are connected by dotted lines. Genetic markers are to the right side of each linkage group of Pop-DG, genetic distances (cM) are to the left. Markers in bold are fruit texture, pigment, flavor, and $\mathrm{Cl}$ resistance candidate genes. Markers with prefix ' $\mathrm{C}-$ ' are novel Prunus EST-SSRs obtained from the ChillPeach database (Ogundiwin et al. 2008). RAF and SRAP markers start with prefixes 'r' and 's', respectively. Accessory markers are italicized. Markers in blue fonts were heterozygous in 'Georgia Belle' only, markers in red fonts were heterozygous in 'Dr. Davis' only, and all other markers were heterozygous in both parents.

in three locations (linkage groups G2, G3, and G5) were among marker pairs that were close together on the $\mathrm{T} \times \mathrm{E}$ map $(<10 \mathrm{cM})$, suggesting that they are more probably caused by errors in the assignment of marker order than to inversion of chromosome fragments [8].

\section{Simply inherited traits mapped to Pop-DG}

Markers on the Pop-DG linkage map included three simply-inherited Mendelian quality and morphological traits: freestone/clingstone and melting flesh/non-melting flesh (F-M), mesocarp color $(Y)$, and non-showy flower petals (Sh). The Sh locus mapped to linkage group G8 of PopDG. This is the first report of its genomic location since its inheritance was elucidated in the early to mid 1940s. Confirmation of its location on G8 is emerging from some unpublished results (Shenghua Fan and Tatyana Zhebentyayeva, personal communication). This is the only Mendelian trait mapped to G8 of Prunus to date. Linkage group G8 has proved difficult to map in some intraspecific peach mapping efforts [29,34]. In this report also, G8 was the linkage group with fewest number of markers. This could partly explain why it took so long to determine the genomic location of the Sh locus. The F-M (on linkage group G4) and $Y$ (on linkage group G1) loci are among the list of 28 simply-inherited Mendelian traits mapped to Prunus genome in prior studies [8], and their locations are confirmed in Pop-DG.

\section{Novel Prunus EST-SSR markers}

Seventy new Prunus EST-SSR markers were mapped either directly to Pop-DG (21 markers) or bin-mapped to the T $\times$ E reference map (49 markers). The markers were obtained from the ChillPeach EST database [35]. The ChillPeach database is a specialized collection of ESTs from peach mesocarp tissue subjected to cold storage and ripening. The new set of mapped EST-SSR markers provides additional resources for molecular marker analyses in Prunus species.

\section{Identity of mapped CGs}

CG sequence identities were confirmed for endoPG [32], PpLDOX [33], and RIN (data not shown), where fragment lengths and DNA sequence of amplicons corresponded to original EST sequences. The identity of remaining CGs was confirmed by fragment length, where the most intense amplicons were either the expected size (approximately two-thirds of CGs) or were $80-1300$ bp larger presumably due to the inclusion of one or more introns (and confirmed for the aforementioned cases). Identity of CG amplicons was also supported in many cases by previously reported map locations (described below). Further validation via sequencing would be desirable for the remaining CGs, and is the next recommended step for pursuit of specific QTL candidates for fruit quality traits of interest. 
Table I: Features of candidate and cold responsive genes mapped to Pop-DG

\begin{tabular}{|c|c|c|c|c|c|}
\hline LG & Marker Code & Functional Annotation & Clone/Accession \# & EST Source & CG type \\
\hline \multirow[t]{6}{*}{ I } & PL2 & Pectate lyase & BU04|363 & GDR & Texture \\
\hline & Unk23 & similar to FI9PI9.4 protein related cluster & PPI004A08-T7_c_s & ChillPeach & CIRG \\
\hline & PMEI & pectinesterase, putative & BU043277 & GDR & Texture \\
\hline & CND & Chloroplast nucleoid DNA binding protein related cluster & PPN0I8DI0-T7_c_s & ChillPeach & CIRG \\
\hline & SPS & Sucrose phosphate synthase & DY65369I & GDR & Flavor \\
\hline & Aux-IAA & Aux/IAA protein related cluster & CL78ContigI & ChillPeach & CIRG \\
\hline \multirow[t]{2}{*}{2} & $\mathrm{BCH}$ & Beta-carotene-hydroxylase & BU04476I & GDR & Pigment \\
\hline & Unk20 & OSJNBb0039L24. 13 protein & CLI095ContigI & ChillPeach & CIRG \\
\hline \multirow[t]{2}{*}{3} & Unk13 & highly similar to OSJNBb0004AI7.4 protein related cluster & CL32Contig2 & ChillPeach & CIRG \\
\hline & TPI & Thaumatin-like protein I precursor & PPN003H07-T7_c_s & ChillPeach & CIRG \\
\hline \multirow[t]{2}{*}{4} & RIN & $\begin{array}{l}\text { Similar to Solanum lycopersicum MADS-RIN MADS box } \\
\text { transcription factor }\end{array}$ & BU045II6 & GDR & Texture \\
\hline & endoPG & endopolygalacturonase & BU040689 & GDR & Texture \\
\hline \multirow[t]{2}{*}{5} & PpLDOX & Leucoanthocyanidin dioxygenase & EU292217 & Ogundiwin et al., 2008 & Pigment \\
\hline & Ara & Alpha-L-arabinofuranosidase & DQ486870 & $\mathrm{NCBI}$ & Texture \\
\hline \multirow[t]{2}{*}{6} & Unkl0 & No annotation available & PPI005BI0-T7_c_s & ChillPeach & CIRG \\
\hline & Unk19 & No annotation available & PPN024C05-T7_c_s & ChillPeach & CIRG \\
\hline \multirow[t]{4}{*}{7} & SPP & Serine protease-like protein related cluster & PPN007C09-T7_c_s & ChillPeach & CIRG \\
\hline & PME5 & pectin methylesterase - like protein & BU044844 & GDR & Texture \\
\hline & TIP & Tonoplast intrinsic protein related cluster & PPI003C07-T7_c_s & ChillPeach & ChillPeach \\
\hline & ZXE2 & Zeaxanthin epoxidase & CL377Contig I & ChillPeach & Pigment \\
\hline \multirow[t]{4}{*}{8} & Unk5 & No annotation available & PPI004FII-T7_c_s & ChillPeach & CIRG \\
\hline & PG4 & P. persica PG gene & $\times 77231$ & $\mathrm{NCBI}$ & Texture \\
\hline & ST & Sulfate transporter 3.1 & PPN065F08-T7_c_s & ChillPeach & CIRG \\
\hline & Arg2 & Indole-3-acetic acid-induced protein ARG2 related cluster & CL704ContigI & ChillPeach & CIRG \\
\hline
\end{tabular}

a: CIRG = chilling injury resistance genes

\section{Comparing locations of CGs bin-mapped on $T \times E$ to other Prunus maps}

Several previously mapped fruit candidate genes in Prunus corresponded to their genome locations in the present study. The locations of three CGs bin-mapped to $\mathrm{T} \times \mathrm{E}$ in this study corresponded to a previous interspecific 'Padre' $\times$ 54P455 map [13]. Catalase was mapped as an isozyme locus (Cat1) to the top of linkage group G5 of the 'Padre' $\times 54 \mathrm{P} 455$ map. We bin-mapped this texture CG to $\mathrm{T} \times \mathrm{E}$ bin 5:04. In earlier studies, the peach fruit acidity locus (D) was mapped to the top of G5 [25] and a tight linkage between Cat1 and the D locus was also reported [36]. Another isozyme, isocitrate dehydrogenase, was mapped as ICD to the top of linkage group G3 of 'Padre' $\times 54$ P455 [13] and as Icdh1 to T $\times \mathrm{E}$ [37], and we bin-mapped this flavor CG as $I C D H$ to $\mathrm{T} \times \mathrm{E}$ bin 3:06. Dehydrin was mapped as DHN1 and Dehy2 to the middle of group G7 of 'Padre' $\times 54 \mathrm{P} 455$ [13] and T $\times \mathrm{E}$ (in this report), respectively.
The gene encoding polygalacturonase inhibiting protein (PGIP) mapped to different locations in the two studies; it mapped to G7 in 'Padre' $\times 54 \mathrm{P} 455$ and to G6 on T $\times$ E. Different members of the PGIP gene family may have been mapped in the two separate studies. Another independent study bin-mapped the genes endoPG (as EPPCU1775) to bin 4:63, ACO1 (as MD206a) to 3:36, ACO3 (as MD205a) to 4:18, and PG4 (as MD207a) to $8: 63$ to $\mathrm{T} \times \mathrm{E}$ [11]. $P G 4$ was also mapped as isozyme $P G$ to the same end of G8 in an almond linkage map [16]. PEPC was mapped as PEPc in a 'Ferjalou Jalousia' $\times$ 'Fantasia' map [37] in the same region as our PEPC (3:22). These authors [37] also reported the location of another ten candidate genes for sweetness and acidity, and a different expansin gene to those mapped here, to various locations on a peach map using the $\mathrm{T} \times \mathrm{E}$ population. Three further fruit quality CGs were mapped in a separate study [11]: NADP dependent sorbitol 6-phosphate dehydrogenase (as MD201a) for sweetness to bin 8:19, H+ ATPase (as 

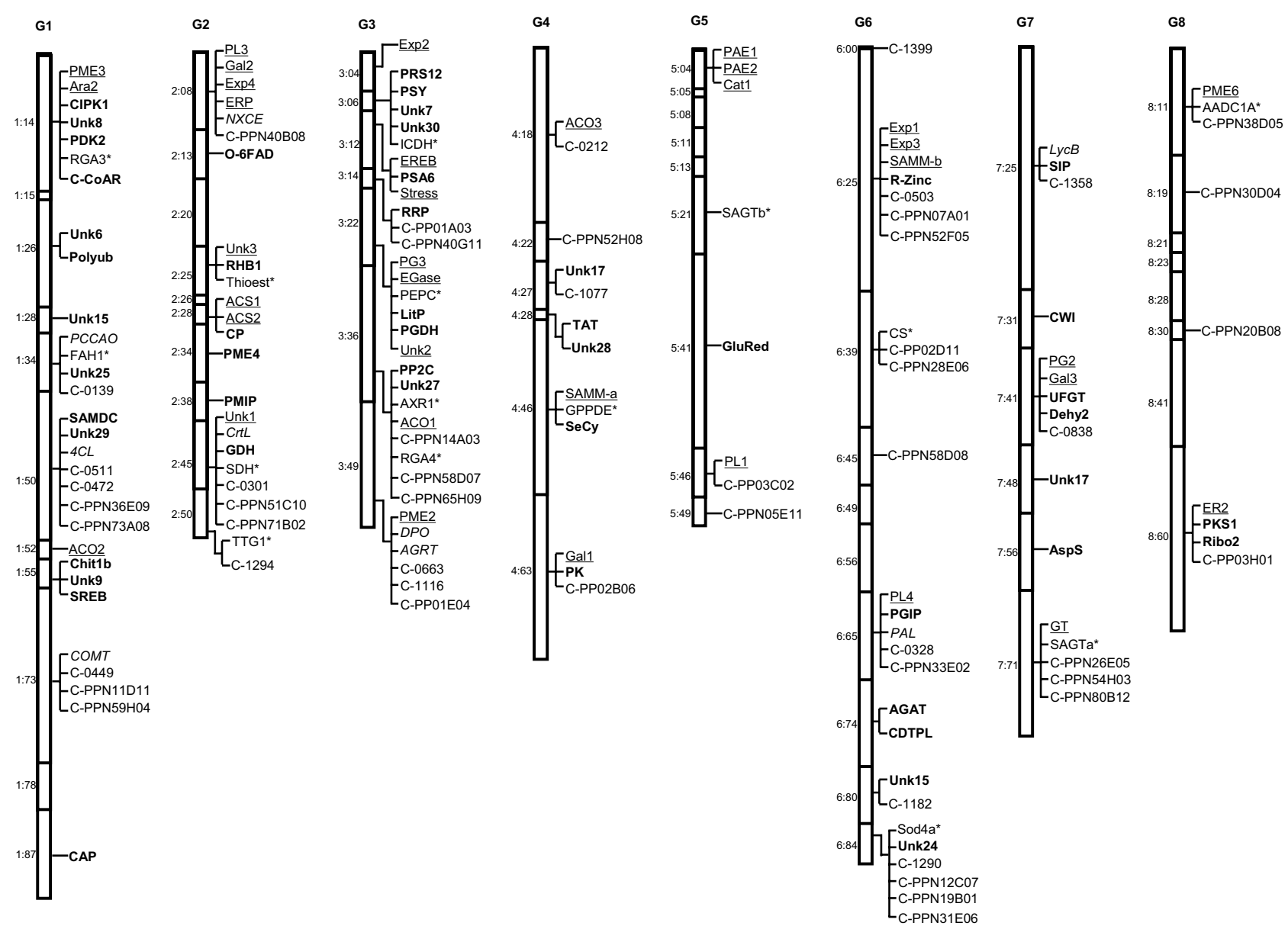

\section{Figure 4}

Candidate genes (CGs) and novel Prunus EST-SSR markers bin-mapped to the Prunus $\mathrm{T} \times \mathrm{E}$ reference map. Cl resistance CGs are in bold fonts, texture CGs are underlined, CGs related to fruit pigmentation are italicized, other CGs are asterisked, and new Prunus EST-SSRs are in normal font.

MD203a) for sweetness/acidity to bin $1: 73$, and endobeta-1,4-glucanase for texture to bin 5:41 (a different gene family member to our EGase of bin 3:22). Additional fruit quality candidate genes have been located in the Prunus genome during hybridization-based efforts to physically map peach ESTs [4].

\section{Co-locations of candidate genes and chilling injury QTLs}

The co-linearity between the Pop-DG and T $\times$ E maps has begun to yield benefits in dissecting the genetic control of fruit quality traits in peach. We are using the fruit quality gene map to better understand the genetics of resistance to chilling injury, particularly focusing on the major symptoms of mealiness, browning, and bleeding. At least two cases of co-localizations of chilling injury QTLs and CGs mapped to Pop-DG/T $\times$ E were previously reported:
endoPG on G4 with major QTLs for mealiness and bleeding $[31,38,39]$ as well as to the Freestone-Melting flesh locus $[31,32]$ and $P p L D O X$ on G5 with cold storage-induced browning [33].

\section{Mealiness}

A peach homolog of tomato MADS-RIN ripening inhibitor gene $(R I N)$, necessary for fruit ripening in tomato, mapped close $(6 \mathrm{cM})$ to endoPG. Two RIN accessory markers (rin- $a$ and $r i n-b)$ also mapped distally to endoPG. The functional role of RIN in peach fruit ripening, mealiness, or bleeding has not yet been established. Four additional minor QTLs were reported for mealiness in Pop-DG corresponding approximately to $\mathrm{T} \times \mathrm{E}$ bins $4: 18,4: 22-4: 27$, 4:28, and 6:80-6:84 [39]. We mapped one texture CG (ACO3) to bin 4:18, one CI resistance CG (Unk17) to bin 
4:27, two CI resistance CGs (TAT and Unk28) to bin 4:28, and two CI resistance CGs (Unk15 and Unk24) to bins 6:80-6:84. ACO3 encodes 1-aminocyclopropane-1-carboxylate oxidase, a critical enzyme in ethylene biosynthesis. TAT (tyrosine aminotransferase) is an inducible protein in the plant methyl jasmonate defense system [40]. Unk15, Unk17, Unk24, and Unk28 are genes of unknown functions that were differentially regulated in cold-treated peach mesocarp tissue [35]. Each of these CGs are potential markers for mealiness resistance and warrant further investigation.

\section{Flesh browning}

Some CGs mapped to locations where QTLs have been reported for cold storage-induced flesh browning in peach fruit. A major browning QTL was located on linkage group G5 of Pop-DG corresponding to bin 5:21 of T $\times$ E [33,39]. $P p L D O X$ (leucoanthocyanidin dioxygenase), which was initially mapped to this bin, was later fine-mapped to Pop-DG, and evidence of its association with browning was established [33]. The two minor browning QTLs reported on linkage group G2 of Pop-DG [39] correspond roughly to bins 2:08-2:13 and 2:20-2:25 of $\mathrm{T} \times \mathrm{E}$ map. Four ripening CGs (PL3, Gal2, Exp4, and ERP) and one pigmentation CG (NXCE) mapped to bin 2:08, and one $\mathrm{CI}$ resistance $\mathrm{CG}(\mathrm{O}-6 \mathrm{FAD})$ mapped to bin 2:13. Also one ripening CG (Unk3) and one CI resistance CG (RHB1) mapped to bin 2:25. PL3 (pectate lyase), Gal2 (beta-galactosidase), and EXP4 (expansin) are cell wall-degrading enzymes while ERP (ethylene-responsive small gtp-binding) is an ethylene-related protein. Unk3 is a protein of unknown function which was up-regulated by ethylene in peach mesocarp tissue [41]. NXCE (neoxanthin cleavage enzyme) is an abscisic acid biosynthesis gene that acts by oxidative cleavage of a carotenoid neoxanthin [42]. O6FAD (omega-6 fatty acid desaturase) and RHB1 (RING$\mathrm{H} 2$ finger protein) were up-regulated in cold-treated peach mesocarp tissue [35]. These CGs may be useful markers for developing resistance to cold-induced browning in stone fruit.

\section{Cold-induced bleeding}

In addition to the major QTL detected in peach fruit at the F-M/endoPG locus on G4 of Pop-DG, two minor QTLs were also reported for cold-induced bleeding on Pop-DG linkage group G1 [39], corresponding to $\mathrm{T} \times \mathrm{E}$ bins 1:14 and 1:34. A texture CG (PL2) and a CI resistance CG (Unk23) mapped close to the minor bleeding QTL peak at the top end of G1. Two texture CGs (PME3 and Ara2) and four CI resistance CGs (CIPK1,PDK2, C-CoAR, and Unk8) mapped to bin 1:14, while PCCAO (pigmentation CG) and Unk25 (CI resistance CG) mapped to bin 1:34. PL2 (pectate lyase), PME3 (pectin methylesterase), and Ara2 (alpha-L-arabinofuranosidase) are cell wall-degrading enzymes $[41,43]$. PPCAO (peroxisomal copper-contain- ing amine oxidase) catalyzes the oxidation of amines to aldehyde, ammonia and hydrogen peroxide [44]. CIPK1 (calcineurin B-like protein-interacting protein kinase), involved in plant calcium signaling [45], PDK2 (pyruvate dehydogenase kinase), C-CoAR (cinnamoyl-CoA reductase), Unk8, and Unk25 were up-regulated in cold-treated mesocarp tissue of peach [35]. These CGs will be further investigated for possible roles in the formation of bleeding and developing bleeding-free peach cultivars.

\section{Inferred co-locations of candidate genes and other published fruit quality traits}

Several CGs mapped to genomic regions corresponding to fruit quality QTLs reported in other studies. Examples are those reported by [34] and [46].

\section{Putative candidate genes for fruit quality QTLs on PI908 × 'Summergrand' map [34]}

On linkage group G1 QTLs were detected by [34] for fructose $\left(F r u_{1,2}\right)$, sweetness $\left(S w e_{2}\right)$, quinic acid $\left(Q u i_{1}\right)$, fruit cheek diameter $\left(\right.$ FCheekD $\left.{ }_{2}\right)$, fruit mass $\left(\right.$ FMass $\left._{2}\right)$, and fruit suture diameter $\left(F_{\text {Suture }}\right)$ in the region corresponding to the $\mathrm{T} \times \mathrm{E}$ bin 1:26 on which we bin-mapped Polyub (Polyubiquitin) and Unk6; QTLs for citric acid (Cit $\left.{ }_{1}\right)$ and total sugar (TSugar ${ }_{1}$ ) in the region equivalent to bin 1:50 of $\mathrm{T} \times \mathrm{E}$ on which we bin-mapped SAMDC (S-adenosylmethionine decarboxylase), Unk29, 4CL (4-coumarateCoA ligase-like protein), C-0472 (6-phosphogluconolactonase), C-PPN36E09, C-PPN73A08; QTLs for total sugar (TSugar ${ }_{2}$ and quinic acid $\left(Q u i_{2}\right)$ in the region corresponding to bin 1:52-1:55 of T $\times$ E where we bin-mapped Chitb (Chitinase Ib), Unk9 and SREB (Sucrose-responsive element binding protein). Notable among these gene markers are those encoding sucrose-responsive element binding protein (SREB) and phosphogluconolactonase (C-0472) for their possible involvement in sugar biosynthesis [47] and inducible expression [48], respectively. In addition, [34] localized QTLs for sucrose ( $\left.S u c_{1}, S u c_{2}\right)$, glucose $\left(G l u_{2}\right)$, and quinic acid $\left(Q u i_{1}\right)$ on linkage group G7 region comparable to bin 7:56 of $\mathrm{T} \times \mathrm{E}$ containing binmapped CG AspS (Asparagine synthetase). The expression of AspS has been shown to increase with a decrease in sucrose levels [49].

The following QTLs were also detected for peach fruit quality on linkage group G4 by [34]: fruit mass (FMass 2 ), fruit polar diameter $\left(\right.$ FPolarD $\left._{2}\right)$, soluble solid concentrate $\left(S S C_{1,2}\right)$ and juiciness $\left(\mathrm{Jui}_{2}\right)$ on a region corresponding to bin 4:18 of T $\times$ E on which ACO3 and C-0212 (Acetyl CoA acetyltransferase) were bin-mapped; and citric acid $\left(\mathrm{Cit}_{2}\right)$, quinic acid $\left(\mathrm{Qui} \mathrm{i}_{2}\right)$, total acid $\left(\mathrm{TAcid}_{2}\right)$, sorbitol $\left(\right.$ Sor $\left._{1,2}\right)$, fructose $\left(\mathrm{Fru}_{1}\right)$ and malic acid $\left(\mathrm{Mal}_{1}\right)$ on a region equivalent to bin 4:27 - 4:28 of $\mathrm{T} \times \mathrm{E}$ on which were binmapped Unk17, Unk28, C-1077, and TAT (putative tyrosine aminotransferase). The authors also localized the fol- 
lowing peach fruit quality QTLs on linkage group G5: glucose $\left(G l u_{2}\right)$, fruit suture diameter $\left(F S u t u r e D_{2}\right)$, and fruit cheek diameter $\left(F C h e e k D_{2}\right)$, as well as the major locus controlling fruit acidity, $D$, on a region corresponding approximately to bin 5:04 of $\mathrm{T} \times \mathrm{E}$ on which we binmapped PAE1, PAE2, and Cat1; red skin coloration $\left(S R\right.$ Color $\left._{2}\right)$, dry flesh mass content $\left(D F M C_{1}\right)$, soluble solid concentrate $\left(S S C_{1}\right)$, fruit mass (FMass 1$)$, fruit polar diameter $\left(F\right.$ Polar $\left.D_{1,2}\right)$, and fruit suture diameter $\left(F\right.$ Suture $\left.D_{1}\right)$ on bin 5:46-5:49 of $\mathrm{T} \times \mathrm{E}$ on which PL, C-PP03C02, and $C$ PPN05E11 (SufE-like protein) were bin-mapped. SulfErelated proteins have been implicated in $\mathrm{Fe}-\mathrm{S}$ metabolism and export [50].

Putative candidate genes for fruit quality QTLs on 'Ferjalou Jalousia' $\times$ 'Fantasia' map [46]

A number of fruit quality QTLs (including fresh weight, sucrose, and SSC) were detected by [46] on linkage group G6 of 'Ferjalou Jalousia' × 'Fantasia' map, on the region corresponding to bin 6:74-6:84 of the $\mathrm{T} \times \mathrm{E}$ linkage map. To this bin, we mapped AGAT (Alanine--glyoxylate aminotransferase), CDTPL (C-terminal domain phosphataselike), Sod4a (Superoxide dismutase), Unk5, Unk24, C1182 (BZIP transcription factor bZIP105), C-1290, CPPN12C07, C-PPN19B01, and C-PPN31E06 (Glutaminefructose-6-phosphate transaminase). Glutamine-fructose6-phosphate transaminase is an important enzyme in biosynthesis of amino sugar-containing macromolecules [51]. Also on linkage group G4, Dirlewanger et al (1999) localized QTLs for SSC and fructose to a region equivalent to the $\mathrm{T} \times \mathrm{E}$ bin 4:46. The candidate genes mapped to this bin were $\mathrm{SeC} y$ (Sesquiterpene cyclase), SAMM (S-adenosylmethionine:2-demethylmenaquinone methyltransferase), and GPPDE (glycerophosphoryl diester phosphodiesterase).

\section{Conclusion}

We have developed a fruit quality gene map for Prunus by determining the genomic locations of 133 fruit quality candidate genes with an intraspecific peach population, Pop-DG, and the Prunus reference map, $\mathrm{T} \times \mathrm{E}$. Sufficient SSR marker anchoring between both maps allowed easy cross-referencing of marker and trait locus positions. We demonstrate here the use of this gene map for dissecting the molecular genetics of $\mathrm{CI}$ in peach. Using the results of microarray experiments that studied gene expression in cold-treated peach mesocarp tissue, 63 cold-responsive genes were located on the fruit quality gene map, allowing the detection of co-locations of these CI resistance CGs with QTLs for CI symptoms. We also highlight new CGs for previously reported Prunus QTLs of other fruit quality traits. The fruit quality gene map presented here is expected to be a valuable resource for the genetic analysis of fruit ripening and related fruit quality traits in Prunus species.

\section{Methods \\ Mapping population and $T \times E$ bin set}

Pop-DG is a peach intraspecific cross between 'Dr. Davis' (female parent) and 'Georgia Belle' (pollen parent). 'Dr. Davis' is a modern canning peach cultivar while 'Georgia Belle' is a century-old fresh market peach cultivar. These cultivars contrast for many fruit quality and other traits (Table 2, 3). Pop-DG, created and managed to study the genetics of fruit quality attainment and maintenance, particularly resistance to $\mathrm{CI}$, in peach and nectarine, was established in two nearby orchards at Kearney Agricultural Center (Parlier, CA, USA). The first orchard was established in 1998 containing 51 verified hybrids [32]. Each progeny genotype was represented by two trees in the orchard; one tree planted on its own roots and the other tree on 'Nemaguard' rootstock. The second orchard was established in 2002, containing single trees of 277 true hybrid progeny on their own roots. All 51 progeny of the first orchard and 101 progeny of the second orchard (152 true hybrid progeny total) were used for Pop-DG linkage mapping. For bin-mapping in $\mathrm{T} \times \mathrm{E}, \mathrm{DNA}$ samples of the bin set of the 'Texas' $\times$ 'Earlygold' population ('Earlygold' the $\mathrm{F}_{1}$ plant, and six $\mathrm{F}_{2}$ plants) [11], kindly provided by Dr. Werner Howad, were used. We also included the second parent - 'Texas' in each test.

\section{Morphological markers}

Pop-DG segregated for three Mendelian morphological traits: freestone melting flesh/clingstone non-melting flesh, white/yellow flesh color, and non-showy/showy flower petals. These traits were scored visually and included in linkage analysis alongside molecular markers.

\section{Molecular markers}

Various classes of molecular markers were evaluated. These marker classes consisted of genomic sequencederived simple sequence repeats (SSR), expressed sequence tag [EST]-derived SSRs (EST-SSR), ethylenerelated candidate genes (CG), texture CGs, pigmentation CGs, flavor CGs, CI resistance CGs, sequence-related amplified polymorphisms (SRAP), randomly amplified DNA fingerprinting (RAF), and inter-microsatellite amplification (IMA).

Candidate genes were nominated from published works and review articles on physiology and biochemistry of fruit ripening, softening, color (pigmentation), and flavor $[37,41,43,52-71]$. EST sequences of most of the CGs (including those described below) were obtained from the GDR database [5]. Others were obtained from the ChillPeach database [35] and GenBank.

CGs assembled for texture included those putatively encoding ethylene-related enzymes (e.g. aminocyclopropane-1-carboxylate synthases, aminocyclopropane-1-car- 
boxylate oxidases, ethylene receptors, ethylene responsive element binding proteins, s-adenosyl-1-methionine synthases, peptide methionine sulfoxide redutase, and ripening inhibitor protein), although ethylene-related genes are also relevant for other fruit ripening processes. Other texture CGs were those putatively encoding cell walldegrading enzymes (e.g. polygalacturonases, pectinesterases, pectate lyases, glucanases, mannosidases, xyloglucans, glycosylases and expansins). As indicated by [41], cell wall synthesis enzymes were also included (e.g glycosyltransferases and fiber protein enzymes), and from the same study, several genes of unknown function but strongly up-regulated by ethylene in ripening peach fruit were also included.

For pigmentation (skin and flesh color, including browning and bruising), candidate genes were chosen from the carotenoid and anthocyanin biosynthesis pathways (e.g. neoxanthin cleavage enzyme, leucoanthocyanidin dioxygenase, anthocyanidin-3-glucoside rhamnosyltransferase, beta-carotene hydroxylase, lycopene beta cyclase, peroxisomal copper containing amine oxidase, zeanthin epoxidase, geranylgeranyl pyrophosphate synthase, zeta carotene desaturase and phytoene desaturase). Genes encoding diphenol oxidases and polyphenol oxidases were also included.

Flavor CGs included sugar and acid biosynthesis pathway genes (e.g. sucrose synthase, hydroxyl methylglutaryl CoA reductase, cell wall invertase, sorbitol dehydrogenase, phosphoenolpyruvate carboxylase, chalcone synthase, polyketide synthase, alcohol dehydrogenase, and aromatic amino acid decarboxylase).

CI resistance CGs were cold-responsive genes obtained from the results of microarray analysis of cold-treated peach mesocarp tissues versus untreated mesocarp tissues [35]. Selection of CI resistance CGs were made as follows: 25 top performing genes, 24 genes common to peach and

Table 2: Fruit quality attributes of Pop-DG parent cultivars, 'Dr. Davis' and 'Georgia Belle'

\begin{tabular}{lll}
\hline Trait $^{\mathbf{a}}$ & 'Dr. Davis' & 'Georgia Belle' \\
\hline Ripening date & Later & Earlier \\
Skin color & Blush on orange ground & Green/yellow, no blush \\
Flesh color & Yellow-orange & White-cream \\
Stone adhesion & Clingstone & Freestone \\
Flesh texture & Firm, non-melting flesh & Soft, melting flesh \\
Aroma & Bland & Sharp \\
Sweetness (SSC) & II.5 & I3.0 \\
Acidity (TA) & High & Low \\
Mealiness & None & High susceptibility \\
Browning & Medium susceptibility & High susceptibility \\
Bleeding & High susceptibility & Low susceptibility \\
\hline
\end{tabular}

a: TA = titratable acidity, SSC = soluble solids concentrate
Arabidopsis thaliana (ChillPeach microarray data compared with ColdArrayDB: http://cold.stanford.edu/cgibin/data.cgi), and 39 genes unique to peach (i.e. not found in ColdArrayDB).

Published reports were the source of all genomic sequence SSRs (see below) and some EST-SSRs, while most ESTSSRs were newly obtained from the ChillPeach EST database [35]. A total of 153 published Prunus SSRs were screened for polymorphism between the Pop-DG mapping parents. These were $P$. persica SSRs with the prefix BPPCT [72], CPPCT [73], EPPCU (GDR database: [5]), Pchcms \& Pchgms [74], PS [75], UCD-CH [76], and UDP $[77,78]$, and $P$. dulcis SSRs with the prefix UDA [79]. The ChillPeach database provided 76 new EST-SSRs for screening, and the markers were labeled with the prefix 'C' followed by the clone or contig number (e.g. CPPN28F07 and C-1128).

RAF markers were obtained according to [80] protocols using Operon decamer primers AA18, B12, B15, D19, E02, E11, E16, P04, P07 and W06 after preliminary screening of many others via the bulked segregant analysis approach [81] with mealiness phenotypic extremes. SRAP marker analysis was conducted according to [82]. One IMA primer (IMA08: (GA) ${ }^{8} \mathrm{GT}$; [25]) was also used to generate additional molecular markers for Pop-DG.

\section{PCR and PAGE}

All PCR primers were designed using Primer3 software [83]. EST sequences of CGs were examined for microsatellite motifs, and whenever ESTs were part of a contig, the contig was examined for SNPs and indels. Primers were designed to exploit these polymorphic features. Where these features were not observable, sequences at the 3'end of the ESTs were used for designing primers to avoid long introns and target less-conserved 3' UTRs. Generally, primers were designed to limit expected amplicon size to $\leq 300$ bp such that a PCR product even with an intron as long as $1 \mathrm{~kb}$ would still be observable on the large $(50 \times$ $38 \mathrm{~cm}$ ) PAGE plate and $1 \mathrm{bp}$ indels of intron-less amplified fragments could be detected. PCR and PAGE conditions were as reported in Peace et al. (2005b). Primer sequences, annealing temperatures, expected and observed amplicon sizes, and type of polymorphisms are provided (See Additional files 3 and 4).

\section{Map construction}

Linkage analysis was conducted with JoinMap ${ }^{\circledR} 4$ [84]. Linkage parameters were set as 3.0 minimum LOD and 0.45 maximum recombination fraction. The Kosambi mapping function [85] was used to convert recombination fraction to map distances in centimorgans (cM). The marker data type was set as cross-pollination (CP). The bin-mapping procedure followed [11]. 


\section{Authors' contributions}

EAO, CPP, TMG, FAB and CHC conceived the study. TMG, FAB and $\mathrm{CHC}$ generated and established the Pop-DG mapping population. EAO and CPP conducted molecular marker discovery and genotyping, and EAO carried out linkage analysis, map construction and manuscript preparation. DEP also assisted in data analysis. DEP, CPP and FAB provided a very thorough review of the manuscript. All authors read and approved the final manuscript.

\section{Additional material}

\section{Additional file 1 \\ Table S1- Features of dominant amplicons (accessory markers) gener- ated alongside the target PCR products of candidate and cold respon- sive genes mapped to Pop-DG. The data provided represent information on accession number, map location, and fragment size information of dominant amplicons (accessory markers) generated alongside the target PCR products of candidate and cold responsive genes mapped to Pop-DG. Click here for file \\ [http://www.biomedcentral.com/content/supplementary/1471- 2164-10-587-S1.DOC]}

\section{Additional file 2}

Table S2 - Characteristics of 71 new Prunus ChillPeach EST-SSR markers mapped to the peach/Prunus genome. The data provided represent information on unigene, map location, and functional annotation of 71 new Prunus ChillPeach EST-SSR markers mapped to the peach/ Prunus genome.

Click here for file

[http://www.biomedcentral.com/content/supplementary/14712164-10-587-S2.DOC]

\section{Additional file 3}

Table S3 - Characteristics of candidate genes (CGs) bin-mapped to the $T \times E$ reference Prunus map. The data provided represent information on the genome location (bin name), marker code, clone/accession number, source of ESTs, and CG class of all CGs bin-mapped to the $T \times$ E reference Prunus map.

Click here for file

[http://www.biomedcentral.com/content/supplementary/14712164-10-587-S3.DOC]

\section{Additional file 4}

Table S4 - Primer details for candidate genes and EST-SSRs. The data provided represent information on the primer sequence, annealing temperature, amplicons size, and type of polymorphisms for candidate genes and EST-SSRs.

Click here for file

[http://www.biomedcentral.com/content/supplementary/14712164-10-587-S4.DOC]

\section{Acknowledgements}

The assistance of Drs. Howad and Arús for supplying the $T \times E$ bin-set DNA samples is gratefully acknowledged. We thank Dr. Vanaja Konduri for early work on Pop-DG mapping, Dr. Riaz Ahmad for generating SRAP marker data, Josh Williamson for initial investigations of pigmentation CGs in Pop-DG, and Daniel Edge-Garza and Jose Soto for DNA extraction of most of Pop-DG. This research was supported by UC Discovery Grants (bio03-10394 \& bio05-10527) with the Industry-University Cooperative Research Program; by Research Grant No US-4027-07 from BARD, the United States - Israel Binational Agricultural Research and Development Fund; and by California Tree Fruit Agreement.

\section{References}

I. Abbott A, Georgi L, Yvergniaux D, Wang Y, Blenda A, Reighard G, Inigo M, Sosinski B: Peach: The model genome for Rosaceae. Acta Hort 2002, 575: I45-I55.

2. Shulaev V, Korban SS, Sosinski B, Abbott AG, Aldwinckle HS, Folta KM, lezzoni A, Main D, Arús P, Dandekar AM, Lewers K, Brown SK, Davis TM, Gardiner SE, Potter D, Veilleux RE: Multiple models for Rosaceae genomics. Plant Physiol 2008, 157:985-1003.

3. Byrne DH: Isozyme variability in four diploid stone fruits compared with other woody perennial plants. J Hered 1990, 8I:68-7I.

4. Zhebentyayeva TN, Swire-Clark G, Georgi LL, Garay L, Jung S, Forrest S, Blenda AV, Blackmon B, Mook J, Horn R, Howad W, Arús P, Main D, Tomkins JP, Sosinski B, Baird WV, Reighard GL, Abbott AG: A framework physical map for the peach, a model Rosaceae species. Tree Genet Genomes 2008, 4:745-756.

5. Jung S, Staton M, Lee T, Blenda A, Svancara R, Abbott A, Main D: GDR (Genome Database for Rosaceae): integrated webdatabase for Rosaceae genomics and genetics data. Nucleic Acids Res 2008, 36:DI034-DI040.

6. Joobeur T, Viruel MA, de Vicente MC, Jauregui B, Ballester J, Dettori MT, Verde I, Truco MJ, Messeguer R, Battle I, Quarta R, Dirlewanger $E$, Arús P: Construction of a saturated linkage map for Prunus using an almond $\times$ peach F2 progeny. Theor Appl Genet 1998, 97:1034-1041.

7. Aranzana MJ, Pineda A, Cosson P, Dirlewanger E, Ascasibar J, Cipriani G, Ryder CD, Testolini R, Abbott A, King G], lezzoni AF, Arús P: A set of simple-sequence repeat (SSR) markers covering the Prunus genome. Theor Appl Genet 2003, 106:819-825.

8. Dirlewanger E, Graziano E, Joobeur T, Garriga-Caldere F, Cosson P, Howard W, Arús P: Comparative mapping and marker assisted selection in Rosaceae fruit crops. Proc Natl Acad Sci USA 2004, I $01: 9891-9896$

9. Arús $P$, Yamamoto T, Dirlewanger E, Abbott AG: Synteny in the Rosaceae. In Plant Breeding Reviews Volume 27. Edited by: Janick J. Hoboken: Wiley; 2006:172-2II.

10. Abbott AG, Arús P, Scorza R: Peach. In Genome mapping and molecular breeding in plants Edited by: Kole C. Berlin: Springer; 2006:137-156.

II. Howad W, Yamamoto T, Dirlewanger E, Testolin R, Cosson P, Cipriani G, Monforte AJ, Georgi L, Abbott AG: Mapping with a few plants: using selective mapping for microsatellite saturation of the Prunus reference map. Genetics 2005, I7 I: I305-1309.

12. Foolad MR, Arulsekar S, Becerra V, Bliss FA: A genetic map of Prunus based on an interspecific cross between peach and almond. Theor Appl Genet 1995, 9 1:262-269.

13. Bliss FA, Arulsekar S, Foolad MR, Becerra V, Gillen AM, Warburton ML, Dandekar AM, Kocsisne GM, Mydin KK: An expanded genetic linkage map of Prunus based on an interspecific cross between almond and peach. Genome 2002, 45:520-529.

14. Dirlewanger E, Cosson P, Howad W, Capdeville G, Bosselut N, Claverie M, Voisin R, Poizat C, Lafargue B, Baron O, Laigret F, Kleinhentz $M$, Arús $P$, Esmenjaud $D$ : Microsatellite genetic linkage maps of myrobalan plum and an almond-peach hybrid - location of root-knot nematode resistance genes. Theor Appl Genet 2004, 109:827-838

15. Rajapakse S, Belthoff LE, He G, Estager AE, Scorza R, Verde I, Ballard RE, Baird WV, Callahan A, Monet R, Abbott AG: Genetic linkage mapping in peach using morphological, RFLP and RAPD markers. Theor Appl Genet 1995, 90:503-5I0.

16. Viruel MA, Messeguer R, de Vicente MC, Garcia-Mas J, Puigdomenech $P$, Vargas FJ, Arús P: A linkage map with RFLP and isozyme markers for almond. Theor Appl Genet 1995, 9 I:964-97I.

17. Joobeur T, Periam N, de Vicente MC, King GJ, Arús P: Development of a second generation linkage map for almond using RAPD and SSR markers. Genome 2000, 43:649-688.

18. Sánchez-Pérez R, Howad W, Dicenta F, Arús P, Martínez-Gómez P: Mapping major genes and quantitative trait loci controlling agronomic traits in almond. Plant Breed 2007, I 26:3 I0-319. 
19. Hurtado MA, Vilanova S, Romero C, Abbott AG, Llacer G, Badenes ML: Genetic linkage maps of two apricot cultivars (Prunus armeniaca L.) based on molecular markers. Theor Appl Genet 2002, 105: |82-19|.

20. Vilanova S, Romero C, Abbott AG, Llacer G, Badenes ML: An apricot (Prunus armeniaca L.) $F_{2}$ progeny linkage map based on SSR and AFLP markers, mapping plum pox virus resistance and self-incompatibility traits. Theor Appl Genet 2003, 107:239-247.

21. Lambert P, Hagen LS, Arús P, Audergon JM: Genetic linkage maps of two apricot cultivars (Prunus armeniaca $L$.) compared with the almond 'Texas' $x$ peach 'Earlygold' reference map for Prunus. Theor Appl Genet 2004, I08: I I 20-I I 30.

22. Dondini L, Lain O, Geuna F, Banfi R, Gaiotti F, Tartarini S, Bassi D, Testolin R: Development of a new SSR-based linkage map in apricot and analysis of synteny with existing Prunus maps. Tree Genet Genomes 2007, 3:239-249.

23. Olmstead JW, Sebolt AM, Cabrera A, Sooriyapathirana SH, Iriarte G, Wang D, Chen CY, Knaap E van der, lezzoni AF: Construction of an intra-specific sweet cherry (Prunus avium L.) genetic linkage map and synteny analysis with the Prunus reference map. Tree Genet Genomes 2008, 4:897-910.

24. Chaparro JX, Werner DJ, O'Malley D, Sederoff RR: Targeted mapping and linkage analysis of morphological, isozyme, and RAPD markers in peach. Theor Appl Genet I994, 87:805-815.

25. Dirlewanger E, Pronier V, Parvery C, Rothan C, Guye A, Monet R: A genetic linkage map of peach (Prunus persica $L$. Batsch) using morphological, RFLP, isoenzyme, RAPD, and AFLP markers. Theor Appl Genet 1998, 97:888-895.

26. Abbott AG, Rajapakse S, Sosinski B, Lu ZX, Sossey-Alaoui K, Gannavarapu M, Reighard G, Ballard RE, Baird WV, Scorza R, Callahan A: Construction of saturated linkage maps of peach crosses segregating for characters controlling fruit quality, tree architecture and pest resistance. Acta Hort 1998, 465:41-49.

27. Lu Z-X, Sosinski B, Reighard GL, Baird WV, Abbott AG: Construction of a genetic linkage map and identification of AFLP markers or resistance to root-knot nematodes in peach rootstocks. Genome 1998, 41:199-207.

28. Yamamoto T, Shimada T, Imai T, Yaegaki H, Haji T, Matsuta N Yamaguchi M, Hayashi T: Characterization of morphological traits based on a genetic linkage map in peach. Breed Sci 200I, 5I:27I-278.

29. Dirlewanger E, Cosson P, Boudehri K, Renaud C, Capdeville G, Tauzin $Y$, Laigret F, Moing A: Development of a second generation genetic linkage map for peach [Prunus persica (L.) Batsch] and characterization of morphological traits affecting flower and fruit. Tree Genet Genomes 2006, 3:1-13.

30. Bailey JS, French AP: The inheritance of blossom type and blossom size in peach. Proc Am Soc Hort Sci 1942, 40:248-250.

31. Peace CP, Ahmad R, Gradziel TM, Dandekar AM, Crisosto CH: The use of molecular genetics to improve peach and nectarine post-storage quality. Acta Hort 2005, 682:403-409.

32. Peace $\mathrm{CP}$, Crisosto $\mathrm{CH}$, Gradziel TM: Endopolygalacturonase: a candidate gene for Freestone and Melting flesh in peach. Mol Breed 2005, 16:21-31.

33. Ogundiwin EA, Peace CP, Nicolet CM, Rashbrook VK, Gradziel TM, Bliss FA, Parfitt D, Crisosto $\mathrm{CH}$ : Leucoanthocyanidin dioxygenase gene (PpLDOX): a potential functional marker for cold storage browning in peach. Tree Genet Genomes 2008, 4:543-554

34. Quilot B, Wu BH, Kervella J, Genard M, Foulongne M, Moreau K: QTL analysis of quality traits in an advanced backcross between Prunus persica cultivars and the wild related species P. davidiana. Theor Appl Genet 2004, 109:884-897.

35. Ogundiwin EA, Martí C, Forment J, Pons C, Granell A, Gradziel TM Peace CP, Crisosto CH: Development of ChillPeach genomic tools and identification of cold-responsive genes in peach fruit. Plant Mol Biol 2008, 68:379-397.

36. Monet R, Guye A, Roy M, Dachary N: Peach Mendelian genetics a short review and new results. Agronomie 1996, 16:321-329.

37. Etienne C, Moing A, Dirlewanger E, Raymond P, Monet R, Rothan C Isolation and characterization of six peach cDNAs encoding key proteins in organic acid metabolism and solute accumulation: involvement in regulating peach fruit acidity. Physiol Plantarum 2002, I | 4:259-270.
38. Peace CP, Crisosto CH, Garner DT, Dandekar AM, Gradziel TM, Bliss FA: Genetic control of internal breakdown in peach. Acta Hort 2006, 71 3:489-496.

39. Ogundiwin EA, Peace CP, Gradziel TM, Dandekar AM, Bliss FA Crisosto $\mathrm{CH}$ : Molecular genetic dissection of chilling injury in peach fruit. Acta Hort 2007, 738:633-638.

40. Lopukhina A, Dettenberg M, Weiler EW, Hollander-Czytko H: Cloning and characterization of a coronatine-regulated tyrosine aminotransferase from Arabidopsis. Plant Physiol 200I, 126:1678-1687.

41. Trainotti L, Zanin D, Casadoro G: A cell wall-oriented genomic approach reveals a new and unexpected complexity of the softening in peaches. $J \operatorname{Exp}$ Bot 2003, 54:|82|-|832.

42. Bouvier F, D'Harlingue A, Backhaus RA, Kumagai MH, Camara B: Identification of neoxanthin synthase as a carotenoid cyclase paralog. Eur J Biochem 200I, 267:6346-6352.

43. Marin-Rodriguez MC, Orchard J, Seymour GB: Pectate lyases, cell wall degradation and fruit softening. I Exp Bot 2002, 53:2115-2119.

44. Tipping AJ, McPherson MJ: Cloning and molecular analysis of the pea seedling copper amine oxidase. J Biol Chem 1995, 270:16939-16946.

45. Luan S: The CBL CIPK network in plant calcium signaling. Trends Plant Sci 2008, I 4:37-42.

46. Dirlewanger E, Moing A, Rothan C, Svanella L, Pronier V, Guye A, Plomion C, Monet R: Mapping QTLs controlling fruit quality in peach (Prunus persica (L.) Batsch). Theor Appl Genet 1999, 98:|8-3|.

47. Miclet E, Stoven V, Michels PAM, Opperdoes FR, Lallemand J-V, Duffieux F: NMR spectroscopic analysis of the first two steps of the pentose-phosphate pathway elucidates the role of 6 phosphogluconolactonase. J Biol Chem 200I, 276:34840-34846.

48. Ishiguro S, Nakamura K: Characterization of a cDNA encoding a novel DNA-binding protein, SPFI, that recognizes SP8 sequences in the 5 ' upstream regions of genes coding for sporamin and betaamylase from sweet potato. Mol Gen Genet 1994, 244:563-57|.

49. Downs CG, Somerfield SD: Asparagine synthetase gene expression increases as sucrose declines in broccoli after harvest. NZ J Crop Hort Sci 1997, 25: 191- 195.

50. Goldsmith-Fischman S, Kuzin A, Edstrom WC, Benach J, Shastry R, Xiao R, Acton TB, Honig B, Montelione GT, Hunt JF: The SufE sulfur-acceptor protein contains a conserved core structure that mediates interdomain interactions in a variety of redox protein complexes. J Mol Biol 2004, 344:549-565.

5I. Milewski S: Glucosamine-6-phosphate synthase - the multifacets enzyme. Biochim Biophys Acta Prot Struct Mol Enzymol 2002, 1597:173-192.

52. Kader AA, Chordas A: Evaluating the browning potential of peaches. Calif Agr 1984, 38: I4-15.

53. O'Neill SD, Tong Y, Sporlein B, Forkmann G, Yoder Jl: Molecular genetic analysis of chalcone synthase in Lycopersicon esculentum and an anthocyanin-deficient mutant. Mol Gen Genet 1990 224:279-288

54. Bonghi C, Rascio N, Ramina A, Casadoro G: Cellulase and polygalacturonase involvement in the abscission of leaf and fruit explants of peach. Plant Mol Biol 1992, 20:839-848.

55. Martin T, Frommer WB, Salanoubat M, Willmitzer L: Expression of an Arabidopsis sucrose synthase gene indicates a role in metabolization of sucrose both during phloem loading and in sink organs. Plant J 1993, 4:367-377.

56. Cunningham FX, Sun Z, Chamovitz D, Hirschberg J, Grantt E: Functional analysis of the beta and epsilon lycopene cyclase enzymes of Arabidopsis reveals a mechanism for control of cyclic carotenoid formation. Plant Cell 1996, 8:1613-1626.

57. Kalaitzis P, Solomos T, Tucket ML: Three different polygalacturonases are expressed in tomato leaf and flower abscission, each with a different temporal expression pattern. Plant Physiol 1997, I I 3:1303-1308.

58. Hong SB, Tucker ML: Genomic organization of six tomato polygalacturonases and $5^{\prime}$ upstream sequence identity with tapl and win2 genes. Mol Gen Genet 1998, 258:479-487.

59. Chang S, Tan C, Frankel EN, Barrett DM: Low-density lipoprotein antioxidant activity of phenolic compounds and polyphenol 
oxidase activity in selected clingstone peach cultivars. J Agric Food Chem 2000, 48:I47-I5I.

60. Ruperti B, Bonghi C, Rasori A, Ramina A, Tonutti P: Characterization and expression of two members of the peach I-aminocyclopropane-I-carboxylate oxidase gene family. Physiol Plantarum 200I, I I I:336-344.

61. Yamada K, Niwa N, Shiratake K, Yamaki S: cDNA cloning of NADdependent sorbitol dehydrogenase from peach fruit and its expression during fruit development. J Hort Sci Biotechnol 200I, 76:58I-587.

62. Jaakola L, Maatta K, Pirttila AN, Torronen R, Karenlampi S, Hohtola $A$ : Expression of genes involved in anthocyanin biosynthesis in relation to anthocyanin, proanthocyanindin, and flavonol levels during bilberry fruit development. Plant Physiol 2002, 130:729-739.

63. Fridman $E$, Zamir D: Functional divergence of a syntenic invertase gene family in tomato, potato, and Arabidopsis. Plant Physiol 2003, 1 3 I:603-609.

64. lyidogan NF, Bayindirli A: Effect of I-cysteine, kojic acid and 4hexylresorcinol combination on inhibition of enzymatic browning in Amasya apple juice. J Food Eng 2003, 62:299-304.

65. $\mathrm{Li} \mathrm{Y}$, Jones $\mathrm{L}, \mathrm{McQueen-Mason} \mathrm{S:} \mathrm{Expansins} \mathrm{and} \mathrm{cell} \mathrm{growth.} \mathrm{Curr}$ Opin Plant Biol 2003, 6:603-6I0.

66. Trainotti $L$, Pavanello $A$, Zanin D: PpEG4 is a peach endo-betaI,4-glucanase gene whose expression in climacteric peaches does not follow a climacteric pattern. J Exp Bot 2006, 57:589-598.

67. Bagnoli F, Danti S, Magherini V, Cozza R, Innocenti AM, Racchi ML: Molecular cloning, characterization and expression of two catalase genes from peach. Funct Plant Biol 2004, 31:349-357.

68. Wu Z, Burns JK: A beta-galactosidase gene is expressed during mature fruit abscission of 'Valencia' orange (Citrus sinensis). J Exp Bot 2004, 55: I 483-1490.

69. Dal Cin V, Danesin M, Boschetti A, Dorigoni A, Ramina A: Ethylene biosynthesis and perception in apple fruitlet abscision (Malus domestica L. Borck). J Exp Bot 2005, 56:2995-3005.

70. Chaves ALS, de Mello-Farias PC: Ethylene and fruit ripening: From illumination gas to the control of gene expression, more than a century of discoveries. Genet Mol Biol 2006, 29:508-5I5

71. Tieman D, Taylor M, Schauer N, Fernie AR, Hanson AD, Klee HJ: Tomato aromatic amino acid decarboxylases participate in synthesis of the flavor volatiles 2-phenylethanol and 2-phenylacetaldehyde. Proc Natl Acad Sci USA 2006, 103:8287-8292.

72. Dirlewanger E, Cosson P, Tavaud M, Aranzana MJ, Poizat C, Zanetto $A$, Arús $P$, Laigret $R$ : Development of microsatellite markers in peach (Prunus persica (L.) Batsch) and their use in genetic diversity analysis in peach and sweet cherry (Prunus avium L.). Theor Appl Genet 2002, 105: I 27-138.

73. Aranzana MJ, Garcia-Mas J, Carbo J, Arús P: Development and variability analysis of microsatellite markers in peach. Plant Breed 2002, I $21: 87-92$.

74. Sosinski B, Gannavarapu M, Hager LD, Beck LE, King GJ, Ryder CD, Rajapakse S, Baird WV, Ballard RE, Abbott AG: Characterization of microsatellite markers in peach (Prunus persica (L.) Batsch). Theor Appl Genet 2000, I0 I:42I-428.

75. Cantini C, lezzoni AF, Lamboy WF, Boritzki M, Struss D: DNA fingerprinting of tetraploid cherry germplasm using simple sequence repeats. J Am Soc Hort Sci 200I, I 26:205-209.

76. Struss D, Ahmad R, Southwick SM, Boritzki M: Analysis of sweet cherry (Prunus avium L.) cultivars using SSR and AFLP markers. J Am Soc Hort Sci 2003, I 28:904-909.

77. Cipriani G, Lot G, Huang WG, Marrazzo MT, Peterlunger E, Testolin R: AC/GT and AG/CT microsatellite repeats in peach (Prunus persica (L.) Batsch): isolation, characterization and cross-species amplification in Prunus. Theor Appl Genet 1999, 99:65-72.

78. Testolin R, Marrazzo T, Cipriani G, Quarta R, Verde I, Dettori MT, Pancaldi M, Sansavini S: Microsatellite DNA in peach (Prunus persica $L$. Batch) and its use in fingerprinting and testing the genetic origin of cultivars. Genome 2000, 43:5 I2-520.

79. Testolin R, Messina R, Lain O, Marrazzo MT, Huang WG, Cipriani G: Microsatellites isolated in almond from an AC-repeat enriched library. Mol Ecol Notes 2004, 4:459-46I.

80. Waldron J, Peace CP, Searle IR, Furtado A, Wade N, Graham MW, Carroll BJ: Randomly Amplified DNA Fingerprinting: A culmi- nation of DNA marker technologies based on arbitrarilyprimed PCR amplification. J Biomed Biotechnol 2002, 2: | $4 \mid$ I-I50.

8I. Michelmore RW, Paran I, Kesseli RV: Identification of markers lined to diseaseresistance genes by bulked segregant analysis: A rapid method to detect markers in specific genomic regions by using segregating populations. Proc Natl Acad Sci USA I99|, 88:9828-9832.

82. Ahmad R, Potter D, Southwick SM: Genotyping of peach and nectarine cultivars with SSR and SRAP molecular markers. J Amer Soc Hort Sci 2004, I 29:204-2 10.

83. Rozen S, Skaletsky HJ: Primer3 on the WWW for general users and for biologist programmers. In Bioinformatics Methods and Protocols: Methods in Molecular Biology Edited by: Krawetz, S, Misener S. Totowa: Humana Press; 2000:365-386.

84. Van Ooijen JW: JoinMap ${ }^{\circledR}$ 4, Software for the calculation of genetic linkage maps in experimental populations. Kyazma B.V., Wageningen, Netherlands; 2006.

85. Kosambi DD: The estimation of map distance from recombination values. Ann Eugen 1944, I 2:172-175.
Publish with Bio Med Central and every scientist can read your work free of charge

"BioMed Central will be the most significant development for disseminating the results of biomedical research in our lifetime. "

Sir Paul Nurse, Cancer Research UK

Your research papers will be:

- available free of charge to the entire biomedical community

- peer reviewed and published immediately upon acceptance

- cited in PubMed and archived on PubMed Central

- yours - you keep the copyright

Submit your manuscript here:

http://www.biomedcentral.com/info/publishing_adv.asp 